\title{
Book of Seven Seals
}

\section{The Peculiarity of Revelation, its Manuscripts, Attestation, and Transmission Ed. by Thomas J. Kraus and Michael Sommer}

[Das Buch der sieben Siegel. Die Besonderheiten der Offenbarung, ihrer Manuskripte, Zeugnisse und Überlieferung.]

Veröffentlicht auf Englisch.

Die Apokalypse ist ein ganz besonderer Text und ihre spezielle Bedeutung im frühen Christentum wird durch ihre handschriftliche Bezeugung, Überlieferung und literarische Bezüge einerseits und Diskussionen unter den frühen christlichen Schriftstellern andererseits belegt. Genau diese spezielle Bedeutung bildet den Kern dieser Aufsatzsammlung und wird aus unterschiedlichen Perspektiven beleuchtet. Natürlich ist aus moderner Sicht die Apokalypse zu einer Art Fundgrube für Künstler, Komponisten, Dichter und Autoren geworden, denn sie bietet Motive, die heute berühmt und vertraut sind. Gleichzeitig erscheint es wie ein bon mot, dass ihre handschriftliche Überlieferung recht spärlich und eigenartig ist. Durch die Orientierung an Einzelphänomenen, welche die besondere Bezeugung und Überlieferung der Apokalypse betreffen, erhellen die Autoren die Besonderheit der Apokalypse, die bereits in den ersten Jahrhunderten des Christentums wahrgenommen wurde. Ihre handschriftliche Bezeugung und die lebhafte Kontroverse über ihren Wert und ihre Orthodoxie führten dazu, dass die Apokalypse speziell rezipiert wurde.

Inhaltsübersicht

I. The Peculiarity of Majuscules and Minuscules Giovanni Bazzana: Write in a Book what you See and Send it to the Seven Assemblies - Jeff Cate: The Curious Case of Psalm 43 - Thomas J. Kraus: 'When symbols and figures become physical objects:' critical notes about some of the »consistently cited witnesses« to the text of Revelation

\section{The Peculiarity of Reception}

Tobias Nicklas: Christliche Apokalypsen in Ägypten vor Konstantin - Lincoln H. Blumell/Thomas A. Wayment: The 'Number of the Beast' - Martin Meiser: Before Canonisation - MichaelJ. Kruger: The Reception of the Book of Revelation in the Early Church - Jeff Cate: Sisters separated from Birth - Michael Sommer: »Work in progress « - What do Revelation's handwriting tell us about its post-canonical role and function inside the Bible

III. Peculiarities and Miscellaneous

Markus Lembke: Besonderheiten der griechischen Überlieferung des Textes der Offenbarung und ihre Auswirkungen auf die Textkritik - Ulrich Schmid: Editing the Apocalypse in the 21st Century - James H. Charlesworth: The Heavenly Jesus reinterprets Daniel

Thomas J. Kraus Born 1965; studied Catholic Theology and English in Regensburg and Sheffield; 1996-99 Assistant Professor in Regensburg; since 1999 Director of Studies at a Bavarian grammar school; 2000 PhD; since 2013 Teaching Assignments and Habilitation Project in Early Christianity at the Theological Seminary of the University of Zurich; since 2014 Research Fellow at the University of the Free State, Bloemfontein, South Africa.

Michael Sommer Geboren 1984; 2014-20 Juniorprofessor für Bibelwissenschaften an der Martin-Luther-Universität Halle Wittenberg; 2020-22 Vertretungsprofessuren für Neues Testament an den Universitäten München, Regensburg und Duisburg-Essen; aktuell Privatdozent für Neues Testament an der Universität Regensburg.

Jetzt bestellen:

https://mohrsiebeck.com/buch/book-of-seven-seals-9783161542688?no_cache=1

order@mohrsiebeck.com

Telefon: +49 (0)7071-923-17

Telefax: $+49(0) 7071-51104$ 